\title{
2014 Award for Impact on the Teaching and Learning of Mathematics
}

PAUL J. SALLY JR. is the recipient of the inaugural AMS Award for Impact on the Teaching and Learning of Mathematics. Sadly, Paul passed away unexpectedly on December 30, 2013. But news about the award reached him shortly before his death, and he took great pleasure in knowing that he was the first recipient of a prestigious award.

\section{Citation}

Paul Joseph Sally Jr. has combined cutting-edge research with a parallel life-long commitment to education at all levels-precollege, undergraduate, and graduate. As director of undergraduate studies at the University of Chicago for over thirty years, he was a leading voice in the undergraduate program and was seen by many as "a legendary math prof". But what makes Paul Sally the ideal recipient of the inaugural Award for Impact on the Teaching and Learning of Mathematics is his work, which began in the 1960s and continued unabated to the day of his death, in which he established outreach programs for precollege teachers and precollege students.

Important outreach programs that he founded include Seminars for Elementary Specialists and Mathematics Educators (SESAME) that provides State of Illinois middle school mathematics endorsement for teachers in the Chicago public schools, and the Young Scholars Program (YSP) for talented high school students from less than privileged backgrounds. He also cofounded and served as director of the University of Chicago School Mathematics Program (UCSMP), spearheaded the founding of the Chicago Algebra Initiative, and led the mathematics component of Chicago's Urban Teacher Education Program (UTEP).

Not only did he establish programs in Chicago, but he was also instrumental in their expansion to other sites.

One of the purposes of the Award for Impact on the Teaching and Learning of Mathematics is to encourage research mathematicians to be actively engaged in replicable activities that improve mathematics learning and teaching, especially at the precollege level and in the first two undergraduate years. Paul Sally's career is a testament to the achievement of that goal and makes him an eminently excellent choice to be the inaugural recipient of this award.

\section{About Paul J. Sally Jr.}

When Paul J. Sally Jr. died on December 30, 2013, at the age of eighty, the mathematical community mourned the loss of a beloved figure who contributed to the field in many ways, particularly through his teaching, and who did so with an enthusiasm that was infectious. Anyone who ever met Paul could not have helped being struck by the figure he presented: a six-foot-three-inch tall man, who later in his life was bald, had a black eye patch, and had two prosthetic legs. He lost his eyesight and his legs to Type 1 diabetes that had afflicted him since his teenage years. Those losses seemed a hindrance neither to his commanding yet cheerful personality nor to his bottomless energy. He demanded and received total devotion to mathematics from those he worked with,and in his later years was prone to provide the explanation, "because it is

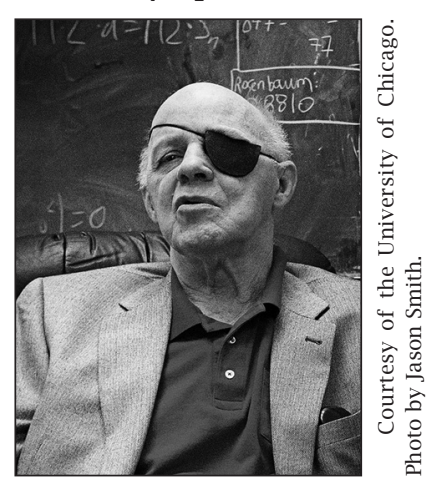

Paul J. Sally Jr. impossible to give a blind double amputee excuses for shirking." This last quotation is lifted from an unsigned memorial posted on the home page of the Mathematics Department at the University of Chicago, but Paul was heard saying this many times himself.

Born in 1933 in Boston, Paul never lost the accent of his hometown. When he visited MIT in 2007, the Boston Globe ran an article about this colorful hometown hero. The article recounted a story Paul told that was set in the Joint Mathematics Meetings. One of Paul's colleagues told Paul that he knew who was getting an award but he refused to tell Paul who it was. So Paul enlisted the help of Philip Kutzko of the University of Iowa to dangle the person from a hotel balcony until he did tell. The story is apocryphal, but Paul milked it for all the humor he could get. "It was only the third floor, but if we had dropped him, it would have been serious," he told the Globe. Later the article quoted Kutzko: "[Paul Sally is] unique because he's this big powerful man, but his hallmark is that he nurtures people. The jokes are funny, but the 
reason his students and colleagues love him is that he's been there for people."

Paul received his bachelor's (1954) and master's (1956) degrees from Boston College. After teaching in Boston high schools and at Boston College-and also driving a cab and a moving truck while playing plenty of basketball (he was an All-Scholastic basketball player in high school and played varsity basketball at Boston College)-he entered the mathematics doctoral program at Brandeis University. While in graduate school, he married fellow graduate student Judith Donovan, now Judith D. Sally, Professor Emeritus of Mathematics at Northwestern University. Paul earned a Ph.D. in 1965 under the direction of Ray Kunze and then joined the faculty at the University of Chicago, where he remained for the rest of his career. In 1967-1968, he was a member at the Institute for Advanced Study. There he came into contact with Harish Chandra, who made a deep impression and stimulated some of Paul's best mathematical work, including his papers with Joseph Shalika on $S L(2)$, which ushered in an era of rapid development in harmonic analysis on reductive $p$-adic groups. Paul had three other year-long stays at the IAS and, along with Murray Gerstenhaber, helped to found AMIAS (the Association of Members of the IAS).

Paul had thirty-seven publications in MathSciNet, and he supervised the Ph.D. theses of nineteen students. His noteworthy research accomplishments were intertwined with his main love: teaching. Arnold Ross, founder of the celebrated program at Ohio State University for mathematically talented high school students, once said that outstanding teachers are "people who respect struggles with ideas and have gone through that themselves and were victors." This was true of Paul. In fact, one of his favorite mottoes was "To teach math, you better know some." (Paul was a great admirer of Ross and in 1996 established an endowment that today helps to fund the AMS Arnold Ross Lecture series.) In 1988, Paul launched his own Young Scholars Program at the University of Chicago for seventh to twelfth grade students. By that time he had had a great deal of experience working with students and teachers in the Chicago public schools. In 1983, the University of Chicago School Mathematics Project (UCSMP) was founded, and Paul was named director. He served in that post until 1987, when he became more involved in the staff development activities of UCSMP.

In 1992, he started SESAME (Seminars for Elementary Specialists and Mathematics Educators), which has since reached over 600 teachers from 125 schools. Many aspects of the programs he ran were emulated by other programs around the country. Paul had a long association with the AMS and served the Society in several capacities: He was a member of the AMS Council and the Board of Trustees (in each case for a total of ten years), and he was on numerous committees, including the Long Range Planning Committee, the Committee on Science
Policy, the Committee on Education, and the Nominating Committee. In 2013, he was among those named in the initial class of Fellows of the AMS. His other honors include the AMS Distinguished Public Service Award (2000) and the Haimo Award for Distinguished University Teaching from the Mathematical Association of America (2002).

When Paul received the AMS Distinguished Public Service Award, the citation praised his "longitudinal mentoring of students." With his characteristic irreverent humor, Paul wrote in his response that he was very honored to receive the award "and as soon as I figure out what 'longitudinal mentoring' means, I'll feel really good." What would he have written in response to receiving the AMS Impact Award? This we cannot know. We will have to content ourselves with memories of this unique individual who contributed so much to mathematics, to education, and to the people whose lives he touched.

There are several excellent sources of information about Paul Sally on the Web, including a profile called "Sally marks the spot", by Carrie Golus, University of Chicago Magazine,http:/7 magazine.uchicago.edu/0856/features/ sa77y.shtm7; and the video interviews with Paul Sally on the Science Lives website of the Simons Foundation, https://www. simonsfoundation. org/science_lives_video/paul-sally/

\section{About the Award}

The AMS Award for Impact on the Teaching and Learning of Mathematics was established by the AMS Committee on Education (COE) in 2013. The Award is given annually to a mathematician (or group of mathematicians) who has made significant contributions of lasting value to mathematics education. Priorities of the award include recognition of (a) accomplished mathematicians who have worked directly with precollege teachers to enhance teachers' impact on mathematics achievement for all students or (b) sustainable and replicable contributions by mathematicians to improving the mathematics education of students in the first two years of college. The US $\$ 1,000$ award is given annually. The recipient is selected by the COE. The endowment fund that supports the award was established in 2012 by a contribution from Kenneth I. and Mary Lou Gross in honor of their daughters, Laura and Karen. The award is presented by the AMS COE acting on the recommendation of a selection subcommittee. For the inaugural award, the members of the subcommittee were Arthur Benjamin, Irwin Kra (chair), and Kay Somers.

- Kenneth I. Gross University of Vermont

- Allyn Jackson Notices Deputy Editor 